\title{
2022 Everett Mendelsohn Prize
}

\author{
Karen Rader ${ }^{1} \cdot$ Marsha Richmond $^{2}$
}

Accepted: 14 February 2022 / Published online: 23 February 2022

(C) The Author(s), under exclusive licence to Springer Nature B.V. 2022

We are delighted to announce the 2022 recipient of the Everett Mendelsohn Prize: Ryan Hearty, whose essay, "Redefining Boundaries: Ruth Myrtle Patrick's Ecological Program at the Academy of Natural Sciences of Philadelphia, 19471975," appeared in the Journal of the History of Biology vol. 53, no. 4 (December 2020), 1-44.

The Mendelsohn Prize, instituted in 2016 to honor the founding editor of $J H B$ who served for its first 31 years and fundamentally shaped the field of the history of biology, is given to the best article published in $J H B$ in the preceding 3 years.

The prize committee, which consists of the Co-Editors-in-Chief and the Associate Editors Luis Campos and Nick Hopwood, considered all 56 articles appearing in volumes 52 (2019), 53 (2020), and 54 (2021). The committee judged the entries based on an assessment of originality, scholarship, and significance for the history of biology.

Hearty's article provides a compelling account of the career of Ruth Patrick (1907-2013), a mid-twentieth-century ecologist and taxonomist who developed techniques in limnology to measure the effects of pollution on aquatic organisms at a time when industrial pollution of waterways was attracting growing concern. The "Patrick principle" gauges the health of river systems by species diversity and abundance. At a time when women faced significant hurdles to gain paid employment in scientific research, Patrick engaged in institution building at the Academy of Natural Sciences of Philadelphia, where she established and headed a Department of Limnology. To this end, she relied on the support of leading ecologists, notably G. Evelyn Hutchinson at Yale, to legitimize her multidisciplinary research program. As Hearty demonstrates, Patrick was also an enterprising entrepreneur. She tapped new financial resources from major postwar industries, including DuPont and oil companies, to fund limnological research and fill the coffers of the distinguished but financially ailing Philadelphia Academy of Natural Sciences.

Karen Rader

journalofthehistoryofbiology@gmail.com

1 Virginia Commonwealth University, Richmond, VA, USA

2 Wayne State University, Detroit, MI, USA 
Drawing on meticulous archival research, Hearty traces Patrick's strategic development of the Academy's limnology program and reconstructs the intricate web of networks she linked in science, professional and trade societies, regional agencies, corporate boardrooms, and the Academy's own executive board. This enables him to make sense of the full complexity of Patrick's adept crossing of boundaries between the worlds of basic and applied science, and the unexpected synergies she both encountered and constructed between the Academy and industry. Using multiple lenses in the historiography of biology, including gender and institutional analysis, Hearty's scholarly achievement is eminently worthy of the 2022 Mendelsohn Prize. The essay also marks the first contribution to JHB's Topical Collection "Women, Gender, and Sexuality in Biology," edited by Donald Opitz.

Ryan Hearty is currently completing a PhD in history of science and technology at the Johns Hopkins University, where his work focuses on multidisciplinary projects in engineering and applied science. His dissertation reconstructs the history of water-quality management in the United States from 1937 to 1981. It explores how experts-especially biologists, chemists, and engineers-cooperated on projects to define, monitor, and model water quality in rivers on behalf of government agencies and private corporations. Hearty serves as a convener for the Engineering Studies discussion group at the Consortium for History of Science, Technology, and Medicine. Before pursuing graduate training in history of science, he worked as an electrical engineer on NASA's Parker Solar Probe.

On behalf of the 2022 Prize Committee and Springer-Nature International Publishing, we congratulate Ryan Hearty on receiving the 2022 Mendelsohn Prize. Hearty's article will be freely available on the $J H B$ website for eight weeks, March and April 2022, and he will receive an honorarium of $\$ 500$.

Publisher's Note Springer Nature remains neutral with regard to jurisdictional claims in published maps and institutional affiliations. 